Volume 6, Nomor 1, Tahun 2017, Halaman 11-18

Online di : http://ejournal-s1.undip.ac.id/index.php/jnc

\title{
PERBEDAAN AKTIVITAS FISIK, SCREEN TIME, DAN PERSEPSI IBU TERHADAP KEGEMUKAN ANTARA BALITA GEMUK DAN NON-GEMUK DI KOTA SEMARANG
}

\author{
Zulfah Asy Syahidah, Hartanti Sandi Wijayanti ${ }^{*}$ \\ Program Studi Ilmu Gizi Fakultas Kedokteran Universitas Diponegoro \\ Jln. Prof. H. Soedarto, SH., Semarang, Telp (024) 8453708, Email : gizifk@ undip.ac.id
}

\begin{abstract}
Background: Obesity is one of the nutritional problem which its prevalence is always increasing every year. Physical inactivity and high screen time, might promote the development of obesity. Childhood obesity is often unrecognized as a problem and wrongly perceived by parents. The wrong perception of childhood obesity may lead to the unsuccessful obesity prevention management.

Objective: The research aimed to figure out the odd risk and the differences of physical activity, screen time, and mother's perception of childhood obesity among obese and non-obese children.

Method: An observational research with case-control-study conducted in Bangetayu and Jangli, Semarang, involved 58 children aged 24-59 month and their mothers. Weight and height data were collected using anthopometric measurement. Physical activity data, screen time, and mother's perception were collected by interviewing questionnaire and analized by Chi Square.

Result: Low physical activity level among obese was 20(68,9\%) and non-obese was 11(37,9\%). High screen time among obese was 25(86,3\%) and non-obese was 11(37,9\%). Negative perception among obese was 15(51,7\%) and non-obese was $17(58,6 \%)$. The differences of physical activity, screen time, and mother's perception were $p=0,034(O R=3,63)$, $p<0,001(O R=10,22)$, and $p=0,792$ respectively.

Conclusion: There were differences of physical activity and screen time among obese and non-obese children, but no difference of mother's perception of childhood obesity among the two groups. Children with low physical activity were 3,6 times at risk of obesity, meanwhile children with high screen time were 10,2 times at risk of obesity.
\end{abstract}

Keywords: children under-five, obesity, physical activity, screen time, mother's perception

\begin{abstract}
ABSTRAK
Latar Belakang: Kegemukan merupakan masalah gizi balita yang terus meningkat. Kurangnya aktivitas fisik dan lamanya menatap layar elektronik (screen time) dapat memicu kegemukan. Kegemukan pada balita kurang disadari orang tua sebagai suatu masalah. Persepsi ibu berperan penting dalam mengelola asupan dan aktivitas fisik anak yang berpengaruh terhadap kegemukan balita.

Tujuan: Tujuan penelitian ini adalah untuk mengetahui perbedaan aktivitas fisik, screen time, dan persepsi ibu terhadap kegemukan antara balita gemuk dan non-gemuk, serta besar risikonya.

Metode: Penelitian observasional dengan pendekatan kasus-kontrol dilakukan di Kelurahan Bangetayu Kulon dan Kelurahan Jangli, Semarang melibatkan 58 balita berusia 24-59 bulan beserta ibunya. Pengumpulan data meliputi identitas sampel, berat badan (BB), tinggi badan (TB), aktivitas fisik (AF), screen time (ST), dan persepsi ibu terhadap kegemukan balita. Data BB dan TB diambil melalui pengukuran antropometri, data AF, ST, dan persepsi diambil melalui wawancara dengan instrumen kuesioner, dianalisis dengan uji Chi Square.

Hasil: Aktivitas fisik kurang ditemukan pada kelompok gemuk sebanyak 20(68.9\%) dan kelompok non-gemuk 11(37.9\%). Screen time tinggi terdapat pada kelompok gemuk sebanyak 25(86.3\%) dan kelompok non-gemuk 11(37.9\%). Persepsi negatif ibu terhadap kegemukan ditemukan pada kelompok gemuk sebanyak 15(51,7\%) dan kelompok non-gemuk 17(58,6\%). Perbedaan aktivitas fisik, screen time, dan persepsi ibu terhadap kegemukan balita ditunjukkan berturutturut oleh $p=0,034$ (OR=3,63; 95\% CI:1,22;10,78), $p<0,001$ (OR=10,22; 95\% CI:2,80;37,33), dan p=0,792.

Simpulan: Terdapat perbedaan aktivitas fisik serta screen time antara balita gemuk dan non-gemuk. Namun, tidak terdapat perbedaan mengenai persepsi ibu terhadap kegemukan balita pada kedua kelompok. Balita dengan aktivitas fisik kurang berisiko 3,63 kali lebih besar untuk mengalami kegemukan, sementara balita dengan screen time yang tinggi berisiko 10,2 kali lebih besar untuk mengalami kegemukan.
\end{abstract}

Kata kunci : balita, obesitas, aktivitas fisik, screen time, persepsi ibu

\section{PENDAHULUAN}

Kegemukan adalah suatu kondisi kelebihan akumulasi lemak di dalam tubuh yang akan menimbulkan masalah kesehatan. ${ }^{1}$ Prevalensi kegemukan terus meningkat dan terjadi tidak hanya di negara maju namun juga negara berkembang.
Prevalensi kegemukan pada balita di Indonesia mencapai $11,9 \%$. Dinas Kesehatan Kota Semarang mendata prevalensi gizi lebih pada balita mengalami peningkatan, dari tahun 2012 sebesar 1,86\% menjadi $2,09 \%$ pada tahun 2013 , menjadi $4,75 \%$ pada tahun $2014 .^{2}$ 
Kegemukan balita merupakan masalah kesehatan yang sangat krusial. Balita gemuk lebih berisiko mengalami masalah kesehatan pada saat ia dewasa, termasuk meningkatkan risiko hipertensi, resistensi insulin, penyakit hati, disfungsi ortopedik, penyakit kardiovaskuler, kanker, kecacatan, dan masalah psikososial. ${ }^{1,2}$ Menghindari risiko kegemukan pada balita dapat dilakukan dengan cara mengatur pola makan dan membiasakan aktivitas fisik bagi balita termasuk olahraga atau bermain. ${ }^{3}$

Aktivitas fisik yang kurang memiliki peran penting dalam memicu kejadian kegemukan. Balita yang memiliki aktivitas fisik ringan berisiko tiga kali lebih besar untuk menjadi gemuk dibanding balita yang memiliki aktivitas sedang atau berat. Kebiasaan bepergian menggunakan kendaraan pribadi memiliki risiko tiga kali lebih tinggi untuk mengalami kegemukan. ${ }^{4,5}$ Penelitian di Manado menunjukkan gambaran aktivitas fisik ringan pada anak gemuk sebesar $85,5 \%$ dan pada anak tidak gemuk $14,7 \% .^{6}$

Perkembangan teknologi saat ini menggeser bentuk kegiatan permainan balita sehingga tidak memerlukan banyak gerak tubuh. Permainan elektronik, seperti komputer, gadget, atau televisi cukup dilakukan dengan duduk, sehingga balita menjadi kekurangan aktivitas fisik. Kegiatan duduk sambil menikmati hiburan elektronik dapat memicu terjadinya kegemukan. ${ }^{7}$ Tiga dari lima balita biasa menghabiskan waktu untuk menonton TV, menggunakan komputer, bermain game melebihi screen time yang direkomendasikan. ${ }^{7}$ Screen time adalah waktu yang digunakan balita selama terpapar media elektronik seperti TV, gadget, smartphone, dan komputer. Menurut American Academy of Pediatrics, screen time perlu dibatasi yaitu kurang dari dua jam per hari. Hasil penelitian terhadap anak usia sekolah di Semarang menunjukkan screen time tertinggi sebesar 5 jam/hari dan terendah 1,82 jam $/$ hari. $^{8}$ Screen time yang melebihi dari 2 jam dapat meningkatkan $50 \%$ risiko mengalami peningkatan IMT dan kegemukan. ${ }^{8,9}$

Kasus kegemukan balita cenderung tidak disadari orang tua sebagai kasus yang berbahaya lalu dianggap hal yang biasa saja. Sebanyak $79 \%$ ibu tidak merasa bahwa anaknya mengalami kegemukan. ${ }^{10}$ Istilah "anak yang gemuk tanda bahwa anak sehat" merebak dan diterima oleh masyarakat luas. ${ }^{11}$ Persepsi orang tua yang salah ini dapat mendukung perkembangan kegemukan pada anak dengan cara mempengaruhi pola makan dan aktivitas fisik anak. ${ }^{12,13}$ Memperbaiki persepsi ibu tentang status gizi anaknya dapat mencegah kegemukan lebih dini, dengan jalan memperbaiki pola makan dan pola aktivitas anak.

Penelitian mengenai aktivitas fisik, screen time, serta persepsi ibu telah banyak dilakukan pada remaja dan anak usia sekolah, namun jarang yang dilakukan pada usia balita. Berdasarkan latar belakang yang telah dipaparkan, penelitian ini dilakukan untuk mengetahui perbedaan aktivitas fisik, screen time, dan persepsi ibu antara balita gemuk dan non-gemuk di kota Semarang, serta besar risikonya (OR).

\section{METODE}

Penelitian ini adalah penelitian observasional yang menggunakan rancangan kasus-kontrol dengan ruang lingkup gizi masyarakat. Populasi target dalam penelitian ini adalah seluruh balita di kota Semarang, sementara populasi terjangkau adalah sebanyak 58 balita berusia $24-59$ bulan beserta ibunya di kelurahan Jangli, kecamatan Tembalang, dan kelurahan Bangetayu Kulon, kecamatan Genuk, kota Semarang.

Pengambilan subyek penelitian dilakukan dengan screening terlebih dahulu, berupa pengukuran antropometri yang dilakukan di wilayah tersebut pada hari pelaksanaan posyandu masing-masing RW. Balita diukur berat badan (BB) dan tinggi badan (TB) masing-masing 2 kali. Hasil ukur kemudian dikategorikan menjadi 2 kelompok, z-score BB/TB balita $>$ 2SD masuk dalam kelompok kasus (gemuk) dan z-score $\mathrm{BB} / \mathrm{TB}$ balita $\leq 2 \mathrm{SD}$ masuk dalam kelompok kontrol (non-gemuk). ${ }^{14}$ Dilakukan random sampling pada masing-masing kelompok untuk diambil subyek sebanyak yang dibutuhkan, dengan menyertakan matching by design menurut jenis kelamin dan wilayah tinggal balita. Setelah melakukan pengisian informed consent, dilakukan wawancara dengan metode door to door ke rumah balita terkait identitas sampel, aktivitas fisik balita, screen time balita, serta persepsi ibu balita mengenai kegemukan pada balita.

Variabel bebas penelitian ini adalah aktivitas fisik, screen time, dan persepsi ibu terhadap kegemukan balita, sedangkan variabel terikatnya adalah kejadian kegemukan balita. Aktivitas fisik adalah tingkat aktivitas fisik dan kegiatan balita dalam sehari. Screen time adalah lamanya waktu yang digunakan balita untuk menonton TV, menonton video, serta bermain games menggunakan media elektronik yang memiliki layar seperti, laptop, komputer, tablet, dan handphone dalam satu hari, dihitung berdasarkan menit. Persepsi ibu adalah cara pandang ibu balita dalam mengevaluasi pernyataan seputar kegemukan balita. Persepsi ibu dikategorikan menjadi dua, yaitu persepsi positif dan persepsi negatif. Persepsi positif adalah persepsi ibu yang mencerminkan bahwa ibu sudah memahami bahwa kegemukan merupakan suatu masalah dan harus segera dilakukan pencegahan, sementara persepsi negatif adalah persepsi ibu yang mencerminkan bahwa ibu belum memandang kegemukan sebagai suatu masalah serta mendukung ibu untuk kurang 
perhatian dalam melakukan pencegahan kegemukan balita.

Data yang didapatkan meliputi data identitas sampel, antropometri, dan data variabel bebas. Data identitas sampel meliputi nama, tanggal lahir, jenis kelamin, data identitas orang tua, dan alamat yang didapat dari formulir identitas sampel. Data antropometri meliputi TB yang diukur menggunakan microtoise dengan ketelitian $0,1 \mathrm{~cm}$ serta $\mathrm{BB}$ yang diukur menggunakan timbangan $\mathrm{BB}$ digital dengan ketelitian $0,1 \mathrm{~kg}$. Data aktivitas fisik balita didapat dari kuesioner Early Years-Physical Activity Questionnaire (EY-PAQ) $)^{28}$, hasil wawancara dikategorikan menjadi aktivitas fisik kurang (jika waktu balita bergerak aktif kurang dari 180 menit/hari) dan aktivitas fisik cukup (jika waktu balita bergerak aktif mencapai 180 menit/hari atau lebih) ${ }^{15}$. Data screen time didapat dari kuesioner screen time, dimana hasil wawancara dikategorikan menjadi screen time tinggi (waktu balita terpapar layar elektronik lebih dari 120 menit/hari) dan screen time rendah (waktu balita terpapar layar elektronik maksimal 120 menit/hari) ${ }^{16,17}$. Data persepsi ibu didapatkan dari kuesioner persepsi ibu, yaitu berupa tes ikonografi ${ }^{29}$ dan pernyataan kesesuaian persepsi, dijumlahkan dan dikonversi menjadi skor $\mathrm{T}$ yang memiliki mean 50, kemudian dikategorikan menjadi persepsi positif (skor $\mathrm{T}$ bernilai 50 atau lebih) dan persepsi negatif (skor persepsi kurang dari 50) ${ }^{18}$.

Analisis Chi Square digunakan untuk menganalisis data sehingga diketahui perbedaan aktivitas fisik, screen time, serta persepsi ibu mengenai kegemukan pada balita gemuk dan nongemuk serta besar risikonya. Tingkat kepercayaan yang digunakan adalah $95 \%$.

\section{HASIL}

\section{Karakteristik Subyek Penelitian}

Dari total sampel diketahui jumlah balita perempuan lebih banyak, yaitu sejumlah 32 anak $(55,2 \%)$, daripada jumlah balita laki laki sejumlah 26 anak $(44,8 \%)$. Rerata usia dan tinggi badan dari kedua kelompok tidak memiliki perbedaan. Hal ini menunjukkan bahwa karakteristik balita sampel adalah homogen. Perbedaan bermakna diperlihatkan oleh rerata berat badan serta Z-score $\mathrm{BB} / \mathrm{TB}$ masingmasing kelompok (Tabel 1). Rerata berat badan kelompok gemuk lebih besar $(20,60 \mathrm{~kg} \pm 4,49)$ daripada kelompok non-gemuk $(14,14 \mathrm{~kg} \pm 2,43)$.

Tabel 1. Deskripsi Karakteristik Balita Subyek Penelitian

\begin{tabular}{|c|c|c|c|c|c|}
\hline \multirow[b]{2}{*}{ Karakteristik } & \multicolumn{2}{|c|}{ Gemuk $(n=29)$} & \multicolumn{2}{|c|}{ Non-gemuk $(n=29)$} & \multirow[b]{2}{*}{$\mathbf{p}$} \\
\hline & Rerata & $\begin{array}{c}\text { Simpang } \\
\text { Baku }\end{array}$ & Rerata & $\begin{array}{c}\text { Simpang } \\
\text { Baku }\end{array}$ & \\
\hline Usia balita (bulan) & 45,31 & 9,70 & 45,00 & 9,13 & $0,901^{\mathrm{a}}$ \\
\hline Berat Badan (kg) & 20,60 & 4,49 & 14,14 & 2,43 & $<0,001^{b}$ \\
\hline Tinggi Badan $(\mathrm{cm})$ & 96,12 & 8,93 & 94,87 & 6,65 & $0,123^{a}$ \\
\hline Z-score BB/TB & 3,58 & 1,17 & 0,05 & 1,06 & $<0,001^{a}$ \\
\hline
\end{tabular}

${ }^{\text {a }}$ Uji statistik Independent T-test

${ }^{\mathrm{b}}$ Uji statistik Mann-Whitney

Karakteristik demografis subyek penelitian yang diukur meliputi tingkat pendidikan ibu, pekerjaan ibu, dan tingkat pendapatan keluarga (Tabel 2). Tingkat pendapatan kelompok gemuk cenderung lebih tinggi daripada kelompok nongemuk, namun oleh uji statistik dinyatakan tidak ada perbedaan tingkat pendapatan antara kedua kelompok. Variabel tingkat pendidikan maupun pekerjaan ibu juga tidak menunjukkan perbedaan yang signifikan di antara kedua kelompok. Dapat disimpulkan bahwa dalam penelitian ini karakteristik subyek penelitian antara kedua kelompok homogen dalam hal umur, tinggi badan, pendidikan ibu, pekerjaan ibu, maupun pendapatan kepala keluarga.

Tabel 2. Karakteristik Demografis Subyek Penelitian

\begin{tabular}{|c|c|c|c|}
\hline Karakteristik & $\begin{array}{c}\text { Gemuk } \\
\text { n (\%) } \\
\end{array}$ & $\begin{array}{c}\text { Non-gemuk } \\
\text { n }(\%) \\
\end{array}$ & $\mathbf{p}$ \\
\hline Jenis Kelamin Balita & & & $1,000^{\mathrm{c}}$ \\
\hline Perempuan & $16(55,2)$ & $16(55,2)$ & \\
\hline Laki-laki & $13(44,8)$ & $13(44,8)$ & \\
\hline Tingkat Pendidikan Ibu & & & $1,000^{\mathrm{c}}$ \\
\hline Rendah (SMP atau lebih rendah) & $13(44,8)$ & $13(44,8)$ & \\
\hline Tinggi (SMA atau lebih tinggi) & $16(55,2)$ & $16(55,2)$ & \\
\hline Pekerjaan Ibu & & & $0,300^{\mathrm{c}}$ \\
\hline Tidak Bekerja & $15(51,7)$ & $15(51,7)$ & \\
\hline Bekerja & $14(48,3)$ & $14(48,3)$ & \\
\hline
\end{tabular}




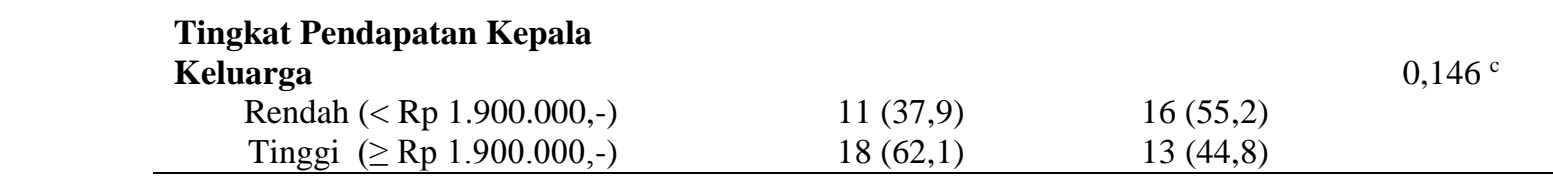

c Uji statistik Chi Square

Perbedaan terdapat pada rerata aktivitas fisik dan screen time antara kedua kelompok. Rerata aktivitas fisik lebih besar dimiliki oleh kelompok non-gemuk, sedangkan rerata screen time lebih tinggi dimiliki oleh kelompok gemuk. Selain perbedaan yang terlihat pada aktivitas fisik dan screen time, skor persepsi ibu justru tidak jelas terlihat berbeda di antara keduanya (Tabel 3). Selain pertanyaan utama mengenai aktivitas fisik, screen time, dan persepsi ibu antara balita gemuk dan non-gemuk, data kebiasaan balita dan ibu yang terkait dengan ketiga variabel ini juga didapatkan (Tabel 4). Kepemilikan media elektronik yang mungkin dapat menjadi pendukung screen time tinggi ternyata tidak menunjukkan perbedaan di antara kedua kelompok.

Tabel 3. Deskripsi Variabel Aktivitas Fisik, Screen Time, dan Persepsi Ibu terhadap Kegemukan

\begin{tabular}{|c|c|c|c|c|c|c|}
\hline \multirow[b]{2}{*}{$\begin{array}{c}\text { Karakte } \\
\text { ristik }\end{array}$} & \multicolumn{3}{|c|}{ Gemuk $(n=29)$} & \multicolumn{3}{|c|}{ Non-gemuk $(n=29)$} \\
\hline & Rerata & $\begin{array}{c}\text { Simpang } \\
\text { Baku }\end{array}$ & $\begin{array}{c}\text { Median } \\
\text { (Min; Max) }\end{array}$ & Rerata & $\begin{array}{c}\text { Simpang } \\
\text { Baku }\end{array}$ & $\begin{array}{c}\text { Median } \\
\text { (Min; Max) }\end{array}$ \\
\hline $\begin{array}{l}\text { Aktivitas } \\
\text { Fisik } \\
\text { (menit } \\
\text { /hari) }\end{array}$ & 188,6 & 158,8 & $\begin{array}{c}117,8 \\
(34,9 ; 660,0)\end{array}$ & 232,3 & 125,2 & $\begin{array}{c}225,0 \\
(23,5 ; 495,0)\end{array}$ \\
\hline $\begin{array}{l}\text { Screen } \\
\text { time } \\
\text { (menit } \\
\text { /hari) }\end{array}$ & 197,5 & 85,2 & $\begin{array}{c}180,0 \\
(40,0 ; 375,0)\end{array}$ & 142,7 & 89,2 & $\begin{array}{c}120,0 \\
(30,0 ; 390,0)\end{array}$ \\
\hline $\begin{array}{l}\text { Skor } \\
\text { persepsi } \\
\text { ibu }\end{array}$ & 49,7 & 10,9 & $\begin{array}{c}48,0 \\
(29,0 ; 69,0)\end{array}$ & 49,2 & 9,0 & $\begin{array}{c}48,0 \\
(36,0 ; 69,0)\end{array}$ \\
\hline
\end{tabular}

Kebiasaan makan balita sambil menonton TV memiliki perbedaan di antara kedua kelompok. Kelompok balita gemuk sebagian besar $(72,4 \%)$ memiliki kebiasaan makan sambil menonton TV. Frekuensi berolahraga atau beraktivitas yang membuat napas terengah-engah pada kelompok gemuk banyak dilakukan hanya $\leq 3 \mathrm{kali} /$ minggu (86,3\%). Ibu balita pada kedua kelompok lebih banyak yang tidak tepat dalam menilai status gizi balitanya, namun pada kelompok gemuk jumlahnya lebih besar $(65,5 \%)$ daripada pada kelompok nongemuk $(55,2 \%)$.

Ketidaktepatan penilaian status gizi diukur melalui jawaban ibu terhadap tes ikonografi, dimana dalam tes tersebut gambar yang menggambarkan proporsi tubuh ideal adalah gambar nomor 4. Gambar nomor 1,2, dan 3 menggambarkan proporsi sangat kurus hingga kurus, sementara gambar nomor 5, 6, dan 7 menggambarkan proporsi gemuk sampai sangat gemuk. Sebanyak 44,8\% ibu memiliki standar yang tepat, namun sebanyak $55,1 \%$ ibu responden tidak tepat dalam mempersepsikan proporsi ideal. Sebanyak 51,7\% mengganggap proporsi ideal adalah gemuk dan 3,4\% ibu menganggap proporsi ideal adalah kurus. Kelompok gemuk menggambarkan 15 orang ibu menganggap balitanya belum gemuk dan 4 orang ibu menganggap balitanya sudah terlampau gemuk, sementara pada kelompok non-gemuk 8 orang menganggap balitanya belum gemuk dan 8 orang ibu menganggap balitanya sudah terlampau gemuk.

Tabel 4. Kebiasaan Balita dan Ibu terkait Aktivitas Fisik, Screen Time dan Persepsi Ibu

\begin{tabular}{lccc}
\hline \multicolumn{1}{c}{ Karakteristik } & Gemuk & Non-gemuk & p \\
\cline { 2 - 3 } & n(\%) & n (\%) & $1,000^{\mathrm{c}}$ \\
Kepemilikan media elektronik & & $11(37,9)$ & \\
$\begin{array}{l}\text { Lebih dari 2 jenis } \\
\text { Hanya 1 atau 2 jenis }\end{array}$ & $10(34,5)$ & $18(62,1)$ & \\
$\begin{array}{l}\text { Kebiasaan makan } \\
\text { menonton TV }\end{array}$ & $19(65,5)$ & & \multirow{2}{*}{$0,033^{\mathrm{c}}$} \\
Ya & & $12(41,3)$ & \\
Tidak & $21(72,4)$ & $17(58,6)$ &
\end{tabular}




\begin{tabular}{|c|c|c|c|}
\hline \multicolumn{3}{|l|}{$\begin{array}{l}\text { Kebiasaan berolahraga atau } \\
\text { aktivitas yang membuat napas } \\
\text { terengah-engah }\end{array}$} & \multirow[t]{2}{*}{$0,038^{\circ}$} \\
\hline$\leq 3 \mathrm{kali} / \mathrm{minggu}$ & $25(86,3)$ & $17(58,6)$ & \\
\hline$>3 \mathrm{kali} / \mathrm{minggu}$ & $4(13,7)$ & $12(41,3)$ & \\
\hline $\begin{array}{l}\text { Penilaian ibu mengenai status } \\
\text { gizi balita }\end{array}$ & & & $0.592^{\circ}$ \\
\hline Tidak tepat & $19(65,5)$ & $16(55,2)$ & \\
\hline Tepat & $10(34,5)$ & $13(44,8)$ & \\
\hline
\end{tabular}

c Uji statistik Chi Square

Perbedaan Aktivitas Fisik, Screen Time, dan Persepsi Ibu terhadap kegemukan antara Balita Gemuk dan Non-gemuk

Perbedaan aktivitas fisik, screen time, dan persepsi ibu terhadap kegemukan antara balita gemuk dan non-gemuk dipaparkan dalam Tabel 5. Hasil uji perbedaan kategori aktivitas fisik antara kelompok balita gemuk dan non-gemuk, secara statistik menunjukkan perbedaan kategori aktivitas fisik antara kelompok balita gemuk dan non-gemuk $(\mathrm{p}=0,034)$. Sebanyak $68,9 \%$ balita gemuk memiliki aktivitas fisik kurang, sementara balita non-gemuk yang memiliki aktivitas kurang sebesar 37,9\%. Balita yang memiliki aktivitas fisik kurang berisiko 3,63 kali lebih besar untuk mengalami kegemukan $(\mathrm{OR}=$ 3,$63 ; 95 \%$ CI:1,22;10,78).

Terdapat perbedaan kategori screen time antara kelompok balita gemuk dan non-gemuk ( $\mathrm{p}<$ 0,001). Screen time tinggi pada penelitian ini dimiliki sebagian besar pada kelompok gemuk yaitu $86,3 \%$, sementara pada kelompok non-gemuk hanya $37,9 \%$. Balita dengan screen time yang tinggi berisiko 10,2 kali lebih besar untuk mengalami kegemukan (OR= 10,22; 95\% CI:2,80;37,33).

Tabel 5. Perbedaan Aktivitas Fisik, Screen Time, dan Persepsi Ibu terhadap Kegemukan pada Balita Gemuk dan Non-Gemuk

\begin{tabular}{|c|c|c|c|c|}
\hline Variabel & $\begin{array}{c}\text { Gemuk } \\
\text { n }(\%) \\
\end{array}$ & $\begin{array}{c}\text { Non-gemuk } \\
\text { n }(\%) \\
\end{array}$ & $\mathbf{p}$ & $\begin{array}{c}\text { OR } \\
(95 \% \mathrm{CI}) \\
\end{array}$ \\
\hline \multicolumn{5}{|l|}{ Aktivitas Fisik } \\
\hline Kurang & $20(68,9)$ & $11(37,9)$ & $0,034^{\mathrm{c}}$ & $3,63(1,22-10,78)$ \\
\hline Cukup & $9(31,1)$ & $18(62,1)$ & & \\
\hline \multicolumn{5}{|l|}{ Screen Time } \\
\hline Tinggi & $25(86,3)$ & $11(37,9)$ & $<0,001^{\mathrm{c}}$ & $10,22(2,80-37,33)$ \\
\hline Rendah & $4(13,7)$ & $18(62,1)$ & & \\
\hline \multicolumn{5}{|l|}{ Persepsi Ibu } \\
\hline Negatif & $15(51,8)$ & $17(58,6)$ & $0,792^{\mathrm{c}}$ & $0,75(0,26-2,13)$ \\
\hline Positif & $14(48,2)$ & $12(41,4)$ & & \\
\hline
\end{tabular}

c Uji statistik Chi Square

Variabel persepsi ibu terhadap kegemukan memiliki hasil uji yang berbeda dengan dua variabel bebas lainnya. Analisis statistik menyatakan tidak terdapat perbedaan kategori persepsi antara kelompok balita gemuk dan non-gemuk $(\mathrm{p}=0,792)$. Sebagian besar ibu balita pada kedua kelompok memiliki persepsi negatif yang ditandai dengan rerata skor yang tak jauh berbeda di antara kedua kelompok $(49,7$ dan 49,2).

\section{PEMBAHASAN}

Hasil penelitian menemukan bahwa terdapat perbedaan aktivitas fisik antara balita gemuk dan balita non-gemuk dengan nilai $p=0,034$. Terlihat bahwa balita gemuk memiliki tingkat aktivitas fisik yang lebih rendah dibandingkan dengan balita nongemuk. Hal ini sejalan dengan penelitian Liu pada 2010, yang mengungkapkan bahwa balita 2-5 tahun yang kurang memenuhi anjuran aktivitas fisik harian, cenderung memiliki status gizi gemuk. ${ }^{3}$ Selain itu, penelitian Danari di Manado juga menyebutkan adanya hubungan antara aktivitas fisik dengan kejadian kegemukan pada anak. Balita yang memiliki $z$-score $\mathrm{BB} / \mathrm{TB}$ normal cenderung bergerak lebih aktif daripada balita yang berstatus gemuk. ${ }^{6}$

Kegemukan merupakan hasil dari ketidakseimbangan antara pemasukan energi yang berasal dari makanan dan pengeluaran energi oleh individu. Jika pemasukan energi lebih besar daripada pengeluaran energi, maka akan terjadi keseimbangan positif. Keseimbangan positif membuat tubuh melakukan penyimpanan energi pada jaringan adiposa sehingga lemak tubuh meningkat. Pemasukan energi perlu diimbangi dengan pengeluaran energi secara cukup. ${ }^{20}$ Aktivitas fisik merupakan pergerakan dari sistem muskuloskeletal 
yang menghasilkan pengeluaran energi. Pergerakan otot pada saat melakukan aktivitas fisik menyebabkan terjadinya pemecahan trigliserida pada jaringan adiposa menjadi asam lemak bebas yang akan diubah menjadi energi. ${ }^{19}$ Aktivitas fisik meningkatkan energy expenditure (pengeluaran energi) yang dapat menyeimbangkan energi. ${ }^{20}$

Nilai ambang batas aktivitas fisik cukup yang digunakan pada penelitian ini adalah 180 menit per hari, sesuai dengan anjuran (guideline) yang berlaku. ${ }^{21,22}$ Pemenuhan 180 menit aktivitas fisik sehari dapat dilakukan oleh balita dengan cara bergerak aktif dan bermain di dalam maupun di luar rumah dengan pengawasan orang dewasa. ${ }^{21,22}$ Memenuhi rekomendasi aktivitas fisik dengan rutin tidak hanya membantu mengontrol kelebihan berat badan namun juga meningkatkan kekuatan dan ketahanan tubuh, menguatkan tulang, meningkatkan kepercayaan diri, dan mengurangi kegugupan serta stress. $^{23}$

Perkembangan teknologi saat ini ikut andil dalam perkembangan obesitas. Menonton TV serta menggunakan media elektronik atau gadget membuat balita dapat duduk tenang dalam waktu yang lama. Perbedaan kategori screen time antara balita gemuk dan balita non-gemuk ditunjukkan dengan nilai $\mathrm{p}$ $<0,001$. Hasil penelitian ini menunjukkan bahwa screen time yang tinggi cenderung dimiliki oleh kelompok balita gemuk daripada balita kelompok non-gemuk. Hasil ini seiring dengan penelitian Ashidiqie di kota Semarang pada anak usia 9-12 tahun. Screen time yang tinggi cenderung dimiliki oleh anak dengan status obesitas daripada status normal. ${ }^{8}$ Anak-anak yang lebih banyak menonton TV memiliki IMT serta persen lemak yang lebih tinggi, dan kurang bergerak aktif. ${ }^{9}$ Aktivitas screen time yang melebihi dari 2 jam dapat meningkatkan 50\% risiko mengalami peningkatan IMT dan kegemukan, ${ }^{8,9}$ sementara pada penelitian ini risiko kegemukan akan menjadi 10,2 kali lipat.

Screen time yang tinggi dapat meningkatkan risiko obesitas lebih tinggi daripada aktivitas fisik yang kurang, karena screen time mempengaruhi obesitas melalui dua jalan, yaitu membuat aktivitas fisik kurang serta membuat asupan meningkat. Screen time yang tinggi membuat waktu balita untuk bermain atau beraktivitas fisik menjadi lebih sedikit. Kebiasaan terlalu lama menonton TV dan terpapar media elektronik juga meningkatkan keinginan balita untuk mengonsumsi makanan dan minuman yang dilihatnya melalui iklan. ${ }^{8}$ Terlalu lama menatap layar elektronik juga membuat balita menjadi tidak sadar akan cemilan yang dikonsumsinya. ${ }^{15}$ Dalam penelitian ini balita yang memiliki status gizi gemuk cenderung lebih senang menikmati waktu makan dengan menonton TV, sementara pada sebagian besar balita non-gemuk waktu makan digunakan untuk fokus makan tanpa mengerjakan kegiatan yang lain.

Persepsi ibu yang berkaitan dengan kegemukan dapat mempengaruhi pola makan dan aktivitas fisik dalam mencegah kegemukan pada anak. ${ }^{10,24}$ Menurut Baugchum, persepsi negatif banyak terjadi pada ibu dengan tingkat pendidikan yang rendah. ${ }^{10,25}$ Pada penelitian ini, tingkat pendidikan ibu tidak berbeda antara kelompok gemuk dan non-gemuk. Kedua kelompok memiliki tingkat pendidikan tinggi dan rendah dengan presentase hampir seimbang. Dengan data ini, dimungkinkan seluruh sampel memiliki persentase persepsi positif dan negatif yang hampir seimbang pula. Namun, hasil penelitian menunjukkan bahwa tidak ditemukan perbedaan persepsi antara kelompok gemuk dan nongemuk $(\mathrm{p}=0,792)$. Masih banyak ibu balita yang memiliki persepsi negatif pada kedua kelompok.

Persepsi negatif dapat membuat ibu kurang tepat dalam menentukan status gizi balitanya. Baugchum dan Warschburger mengungkapkan bahwa ketidaktepatan ibu dalam menilai status gizi anak masih banyak terjadi di masyarakat. ${ }^{10,25}$ Pendapat tersebut juga sejalan dalam hasil penelitian ini, dimana $60,3 \%$ ibu dari kedua kelompok tidak tepat dalam menilai status gizi balitanya, Ketidaktepatan dalam menilai status gizi, membuat ibu menjadi tidak sadar akan kegemukan yang sudah terjadi pada balitanya. Ibu menganggap balitanya tidak mengalami masalah kegemukan, sehingga ibu tidak melakukan tindakan atau sikap pencegahan terhadap obesitas.

Tidak terdapat perbedaan yang signifikan terhadap persepsi ibu antara kedua kelompok dalam penelitian ini. Persepsi ibu tidak berhubungan dengan kejadian kegemukan pada balita, dapat terjadi karena persepsi merupakan sebatas interpretasi cara pandang suatu individu akan apa yang diindera olehnya yang dipengaruhi oleh pengalaman, pendidikan, kebudayaan di sekitar individu tersebut. ${ }^{26}$. Persepsi belum sampai kepada tindakan atau sikap yang selanjutnya dilakukan. Hasil persepsi akan dicerminkan dalam sikap bila faktor lain juga terjadi. Faktor tersebut dapat berupa situasi, norma masyarakat, hambatan maupun pendorong yang ada di lingkungan suatu individu tersebut. Sikap ibu untuk melakukan pencegahan terhadap obesitas akan tergantung pada faktor-faktor tersebut sesuai dengan lingkungan masing-masing. ${ }^{27}$ Bagaimanapun, persepsi juga ikut berpengaruh dalam perubahan sikap seorang individu, dalam hal ini persepsi ibu akan ikut berpengaruh terhadap pengambilan keputusan untuk melakukan pencegahan maupun penanganan kegemukan balita. 


\section{SIMPULAN}

Penelitian ini menunjukkan adanya perbedaan tingkat aktivitas fisik dan screen time antara balita gemuk dan non-gemuk, sedangkan tidak ditemukan perbedaan persepsi ibu terhadap kegemukan antara balita gemuk dan non-gemuk di kota Semarang. Balita dengan aktivitas fisik kurang berisiko 3,63 kali lebih besar untuk mengalami kegemukan sementara balita dengan screen time yang tinggi berisiko 10,2 kali lebih besar untuk mengalami kegemukan.

\section{SARAN}

Masalah kegemukan perlu menjadi perhatian bagi orang tua dan pemerintah dengan meningkatkan program penyuluhan atau sosialisasi gizi yang lebih intensif kepada masyarakat terutama ibu balita tentang bahaya kegemukan dan cara mengelola berat badan balita. Fokus pemberian edukasi adalah dengan topik mengontrol screen time dan penggunaan media elektronik bagi balita serta meningkatkan durasi aktivitas balita sehingga memenuhi rekomendasi.

Penelitian selanjutnya mengenai faktorfaktor yang berpengaruh terhadap persepsi dan perubahan sikap, seperti situasi, norma masyarakat, dan sebagainya, dibutuhkan untuk mengungkapkan bagaimana persepsi dapat berpengaruh terhadap kejadian kegemukan balita.

\section{DAFTAR PUSTAKA}

1. WHO. 2014. Commission on Ending Childhood Obesity. Tersedia dari: http://www.who.int/endchildhood-obesity/facts/en/

2. Dinas Kesehatan Kota Semarang. Profil Kesehatan Kota Semarang. Semarang. 2014.

3. Liu J, Jones SJ, Sun H, Probst JC, Cavicchia P. Diet, Physical Activity, and Sedentary Behaviors as Risk Factors for Childhood Obesity: An Urban and rural Comparison. Columbia: 2010.

4. Mexitalia M, Susanto JC, Faizah Z. Hardian. Hubungan Pola Makan dan Aktivitas Fisik pada Anak dengan Obesitas Usia 6-7 tahun di Semarang. Media Medika Indonesia. 2005.

5. Mahan LK, Escott-Stump S, Raymond JL. Krause's Food and the Nutrition Care Process. 13th Ed. USA: Elsevier Saunders;2012.

6. Danari AL, Mayulu N, Onibala F. Hubungan aktivitas fisik dengan kejadian obesitas pada anak SD di kota Manado. e-Kp. 2013;1(1):1-4

7. Temple JL, Giacomelli AM, Kent KM, Roemmick JN, Epstein LH. Television watching increases motivated responding for food and energy intake in children. Am J Clin Nutr. 2007;85:355-61.

8. Ashidiqie H. Perbedaan jumlah asupan energi, lemak, serat, dan natrium berdasarkan kategori screen time viewing pada anak obesitas usia 9-12 tahun.. [Skripsi]. 2013. Semarang: Program Studi Ilmu Gizi Fakultas Kedokteran Universitas Diponegoro.
9. Sanders, R., Han, A., Baker, J., Cobley, S. (2015). Childhood obesity and its physical and psychological co-morbidities: A systematic review of Australian children and adolescents. European Journal of Pediatrics, 174(6), 715-746.

10. Baugchum AE, Chamberlin LA, Deeks CM, Powers SW, Whitaker RC. Maternal perceptions of overweight preschool children. PEDIATRICS. 2000;106(6):1380-86.

11. Aycan Z. Obesity in Childhood: definition and epidemiology. J Clin Res Ped Endo. 2009;1(suppl):44-53.

12. Hager ER, Candelaria M, Latta LW, Hurley KM, Wang Y, Caulfield LE, Black MM. Maternal perceptions of toddler body size. Arch Pediatr Adolesc Med. 2012;166(5):417-422.

13. Krebs NF, Himas JH, Jacobson D, Nicklas TA, Guilday P, Styne D. Assessment of child and adolescent overweight and obesity. PEDIATRICS. 2007; 120:5193-228.

14. Kemenkes. 2011. Keputusan Menteri Kesehatan Republik Indonesia Nomor 1995/MENKES/SK/XII/2010 tentang Standar Antropometri Penilaian Status Gizi Anak. Jakarta: Kementrian Kesehatan RI Direktorat Bina Gizi.

15. American Academy Pediatrics. Policy StatementChildren, Adolescents, Obesity, and the Media. COUNCIL ON COMMUNICATIONS AND MEDIA.

16. Canadian Paediatric Society. Impact of media use on children and youth. Position Statemment (PP):2014 (01);301-306.

17. American Academy Pediatrics. Children, Adolescents, and Television. PEDIATRICS (107):2001; 423-426.

18. Azwar S. Sikap Manusia Teori dan Pengukurannya. Ed 2. 2011. Yogyakarta: Pustaka Pelajar.

19. Thompson D. Karpe F, Lafontan M, Frayn K. Physical Activity and Exercise in the Regulation of Human Adipose Tissue Physiology. 2012. Physiol Rev: 92; 157-191.

20. Nelms M, Sucher KP, Lacey K, Roth SL. Nutrition Therapy \& Pathophysiology. 2nd Ed. 2011. Wadsworth: Cengage Learning.

21. CSEP. Canadian Physical Activity Guidelines. The Gold Standard in Exercise Science and Personal Training.41

22. Cliff DP, Janssen X. Levels of Habitual Physical Activity in Early Childhood. 2011. Encyclopedia on Early Childhoos Development; 1-5.

23. de Onis M, Blossner M, Borghi E. Global prevalence and trends of overweight and obesity among preschool children. Am J Clin Nutr. 2010;92:125764.

24. Subiakti, DA. Asupan Energi, Lemak, Serat, serta Persepsi Ibu Tentang Obesitas pada Anak Obesitas Dan Non-Obesitas. 2013 [Skripsi]. Semarang: Fakultas Kedokteran Universitas Diponegoro.

25. Sari R. Gambaran persepsi ibu terhadap obesitas pada anak usia prasekolah di kelurahan grogol selatan kebayoran lama jakarta selatan. 2015. [Skripsi]. 
Jakarta: Fakultas Kedokteran dan Ilmu Kesehatan Universitas Islam Negeri Syarif Hidayatullah.

26. Walgito B. Psikologi Sosial (Suatu Pengantar). Ed 3. 2002. Yogyakarta: ANDI.

27. Dewi IC. Hubungan Pengetahuan, Sikap, dan Persepsi Ibu dengan Pemenuhan Kecukupan Gizi Balita (Studi di Posyandu Delima Desa Tiron Kabupaten Kediri). [Tesis]. 2010. Surakarta: Universitas Sebelas Maret.

28. Bingham DD, Collings PJ, Clemens SA, Costa S, Santorelli G, Griffiths P, Barber SE. Reliability and Validity of the Early Years Physical Activity Questionnaire (EY-PAQ). Sports. 2016;4(30):1-14.

29. Hochdorn A, Baldi I, Paramesh EC, Kumar M, Gulati A, Gregori D. Is My Kid Out of Size? Indian Mothers' Desirability Bias in Evaluation of Their Children's Weight. Indian J. Pediatr. 2014;81(1):S39-S46. 